\title{
Physical Characteristics of Black Gram Necrosis Inciting Tobacco Streak Virus on the Cowpea
}

\author{
Natarajan Subramani*, R. Kannan, V. Ramamoorthy and R. Uma Sankareswari \\ Department of Plant Pathology, Agricultural College and Research Institute, Killikulam, \\ Tamil Nadu Agricultural University, Tamil Nadu-628252, India \\ *Corresponding author
}

\section{A B S T R A C T}

\section{Keywords \\ Tobacco streak virus, Blackgram, Necrosis, \\ Dilution end point, \\ Longivity, Thermal \\ inactivation point \\ Article Info \\ Accepted: \\ 16 August 2018 \\ Available Online: \\ 10 September 2018}

Tobacco streak virus (TSV) causes necrosis on leaf, veins, petiole and stem in Blackgram. The sap extracted from the infected blackgram plants remains infectious upto $24 \mathrm{hrs}$ at room temperature. Infectivity of TSV on cowpea progressively reduced in response to increasing in the temperature and dilution. The present investigation was carried out to test the physical properties of TSV such as longevity storage period, thermal inactivation point and dilution end point on Cowpea (CV C- 125) isolated from naturally infected Blackgram plants (CO-8).

\section{Introduction}

Blackgram or Urdbean (Vigna mungo L. Hepper) is an excellent source of easily digestible good quality protein. The Successful cultivation of Blackgram was hindered by both biotic and abiotic factors. Plant pathogens including fungi, bacteria and virus are causing multifarious diseases on Blackgram plants. Among them, viral diseases are causing a drastic reduction on seed yield and quality which leads to serious economic losses (Kang et al., 2005). Urdbean leaf crinkle virus and Mungbean yellow mosaic virus frequently causing diseases on Blackgram were already reported by several researchers (Narayanasamy and Jaganathan, 1973; Srivastava, 2010; Shyam Singh and L.P. Awasthi, 2009). Ladhalakshmi (2002) reported the Tobacco streak virus (TSV) inciting stem necrosis on Blackgram and yield loss of about 20 percent in Coimbatore during 2001. Study on infected plant parts of leaves, stems and seeds of Blackgram necrosis shown a positive reaction with TSV antiserum and purified samples showed isometric particles with a diameter of $27 \mathrm{~nm}$ under Transmission Electron Microscope (Ladhalakshmi et al., 2002). TSV was assigned by the ICTV to the Ilarvirus group as the type member in the family Bromoviridae. TSV was described first by Johnson (1936) and its properties were 
reviewed by Fulton (1970). The variability in the particle size is caused by the encapsulation of the different size of RNAs into separate virions. The size of the coat protein varies from 25 to $30 \mathrm{kDa}$ (Guo et al., 1999). TSV having worldwide distribution, was first discovered in tobacco (Nicotiana tobacum) in Brazil during 1940 (Costa, 1945). Over the 40 years, TSV was reported in crops like cotton, tomato, soybean, peanut, sunflower and some weeds in Brazil (Gracia and Feldman, 1974). In India TSV have been reported in various field crops, including sunflower, peanut, okra and cucurbits (Bhat et al., 2002 a; Bhat et al., 2002b; Prasada Rao et al., 2000; Lava Kumar et al., 2008; Vemana and Jain, 2010).

This study focusses on testing the sap of naturally infected Blackgram plants $(\mathrm{CO}-8)$ on Cowpea (CV C- 125) for the physical properties of TSV such as longevity storage period, thermal inactivation point and dilution end point.

\section{Materials and Methods}

\section{Plant materials and source of the virus}

TSV susceptible Cowpea variety CV C-125 seeds were obtained from Department of pulses, Tamil Nadu Agricultural University, Coimbatore, India. The seeds were sown in pots and raised under glass house condition. Blackgram plants showing typical symptom of necrosis on leaves were collected from Agricultural College and Research Institute, Killikulam, India and were used as source of virus.

The infected plants were identified by the presence of brown, necrotic spots on the young leaves, typical veinal necrosis followed by brown streaks on the petiole and stem. When the disease progresses, the tip of the stem start necrotized and leads to the death of plant.

\section{Virus culture: isolation and extraction}

One gram of infected blackgram leaves exhibiting typical symptoms were taken and sap was extracted by utilizing $3 \mathrm{ml}$ of $0.1 \mathrm{M}$ sodium phosphate buffer ( $\mathrm{pH}$ 7.0) containing mercaptoethanol $(0.1 \%)$ in the precooled pestle and mortar kept in a frozen tray. The sap was mechanically transmitted to primary leaves of cowpea (6 days old), anteriorly dusted with 600-mesh carborundum powder to accommodate as abrasive, described by Hull (2009). The local lesions were produced 6 to 8 days after inoculation on the cotyledonory leaves of cowpea cv C-152 which was the source of inoculum throughout the period of study.

\section{Physical properties of virus}

\section{Dilution end point}

Crude sap was prepared using $0.1 \mathrm{M}$ phosphate buffer at the ratio of 1:2 $(w / v)$ in a precooled pestle and mortar from artificially inoculated cowpea leaves. By serial dilution method, $10^{-1}$ to $10^{-6}$ dilutions were prepared. The plants were inoculated with the sap from each dilution. Each dilution was inoculated on a set of four replication of test plants (cowpea cv C152). Undiluted sap was inoculated on another set of test plants to serve as control. Number of local lesions produced on the plants are observed and compared with the control to determine the dilution end point (Lavanya, 2001).

\section{Thermal inactivation point}

Thermal inactivation point of the virus in a crude juice was found out by taking $20 \mathrm{ml}$ of extract. Two ml sap was pipetted out from the $20 \mathrm{ml}$ extract into a thin-walled test tube, while pipetting out care should be taken to evade contamination in the walls of the test tube with the sap. Then the tubes were immersed in the water bath at temperature 
ranges from $40^{\circ} \mathrm{C}, 45^{\circ} \mathrm{C}, 50^{\circ} \mathrm{C}, 55^{\circ} \mathrm{C}, 60^{\circ} \mathrm{C}$ and $65^{\circ} \mathrm{C}$ for $10 \mathrm{~min}$. After $10 \mathrm{~min}$., tubes were removed and cooled immediately and inoculated on cowpea plants.

Freshly extracted sap that is not subjected to any temperature treatment was inoculated on a set of test plants to serve as control. Number of local lesions produced on the plants are observed and compared with the control to determine the thermal inactivation point (Ladhalakshmi, 2002).

\section{Longevity of the tobacco streak virus under in vitro condition}

The infective sap was extracted and divided into several aliquots of $2 \mathrm{ml}$ in each test tube and stored at room temperature and at $4^{0} \mathrm{C}$. At different time intervals, starting from 0 to 32 $\mathrm{h}$, the sap was inoculated on test plants of cowpea cv C-152 at room temperature. Observation was recorded on the third day after inoculation.

Freshly extracted sap inoculated to a set of test plants served as control. Number of local lesions produced on the test plants were observed and compared with the control to determine the longevity of the virus under in vitro condition (Lavanya, 2001).

\section{Results and Discussion}

\section{Identification and source of the virus}

The Blackgram necrosis infected plants were identified by the presence of brown and necrotic spots on the young leaves, brown streaks on the petiole and stem. This virus causes typical veinal necrosis that systemically spreads to the petiole and stem which leads to death of whole plant. The leaves, petiole and stem of infected plant parts were used as a source of virus (Figure 1 and 2).

\section{Isolation and maintenance of virus culture}

Parts of Blackgram exhibiting the typical symptom of necrosis were collected and inoculated on 6-day old cowpea (C152) plants for multiplication. Invariably on the $8^{\text {th }}$ day after inoculation the leaves produced distinct necrotic local lesions (Figure 3 and 4). The lesions were noticed more on the primary leaves which are subsequently dropped and the trifoliate leaves exhibit necrotic local lesions and the whole plant was died after 10 days.

\section{Graph.1 Thermal inactivation point of the blackgram inciting TSV}

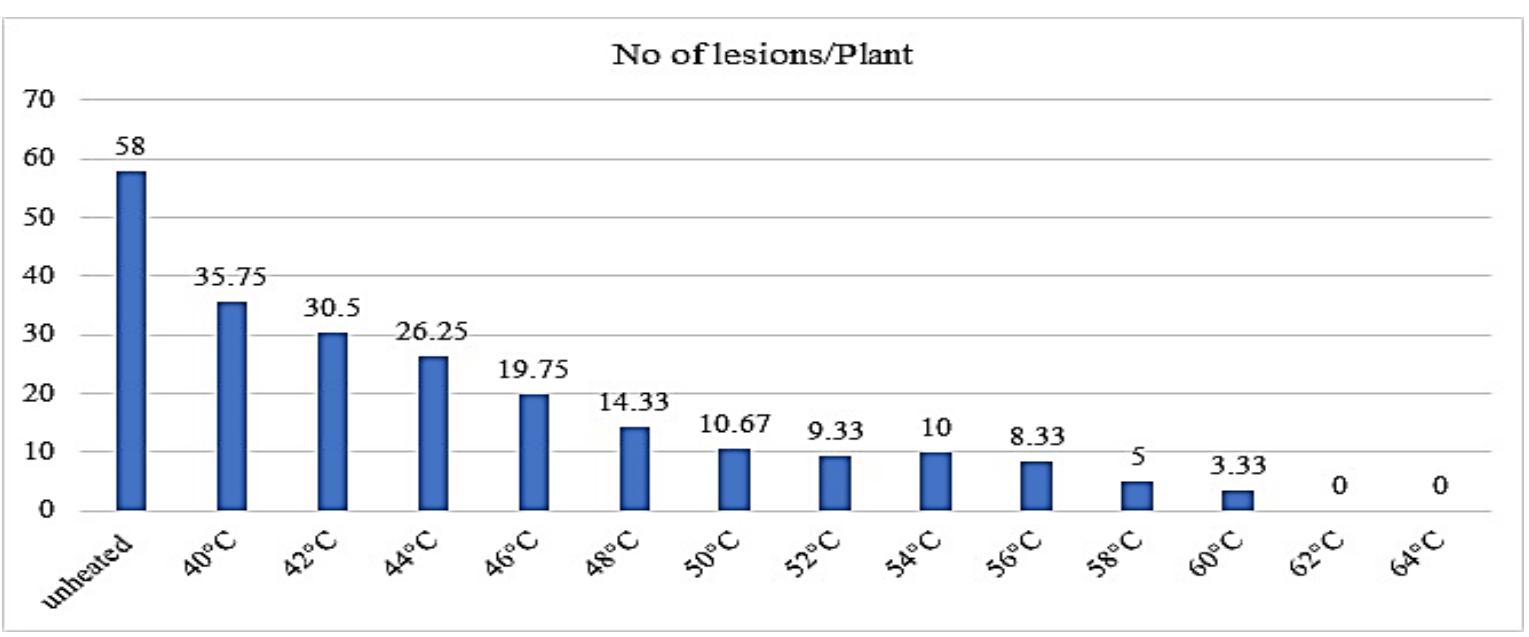


Graph.2 Dilution end point of the blackgram inciting TSV

No of lesions / plant
50.00
30.00
10.00
0.00

Graph.3 Longevity in vitro of the blackgram inciting TSV

\begin{tabular}{ll} 
No of lesions/Plant & \\
\hline
\end{tabular}


Fig.1 Veinal necrosis along with chlorosis on blackgram

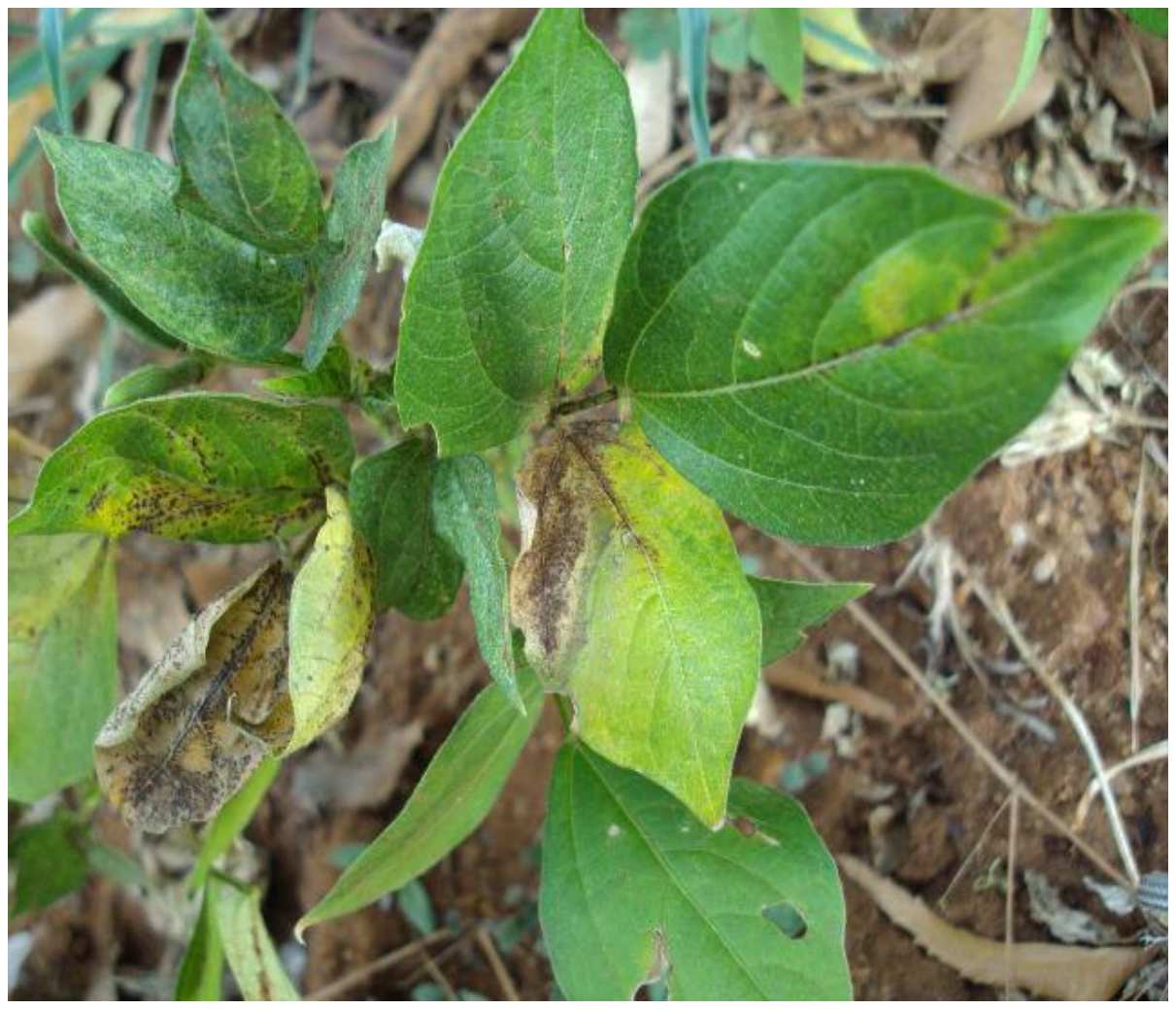

Fig.2 Veinal necrosis along with necrotic streaks on blackgram

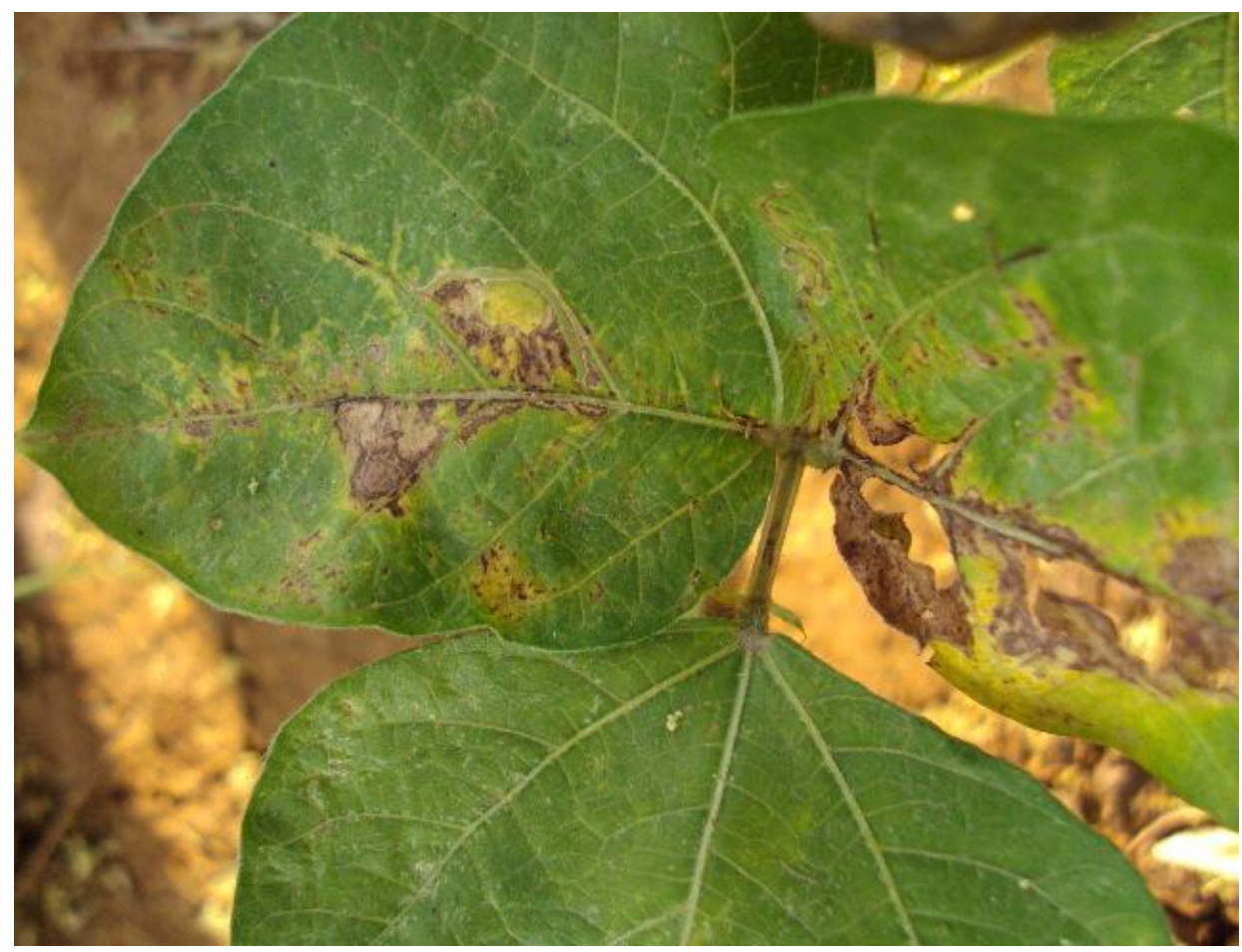


Fig.3 Chlorotic spots on cowpea

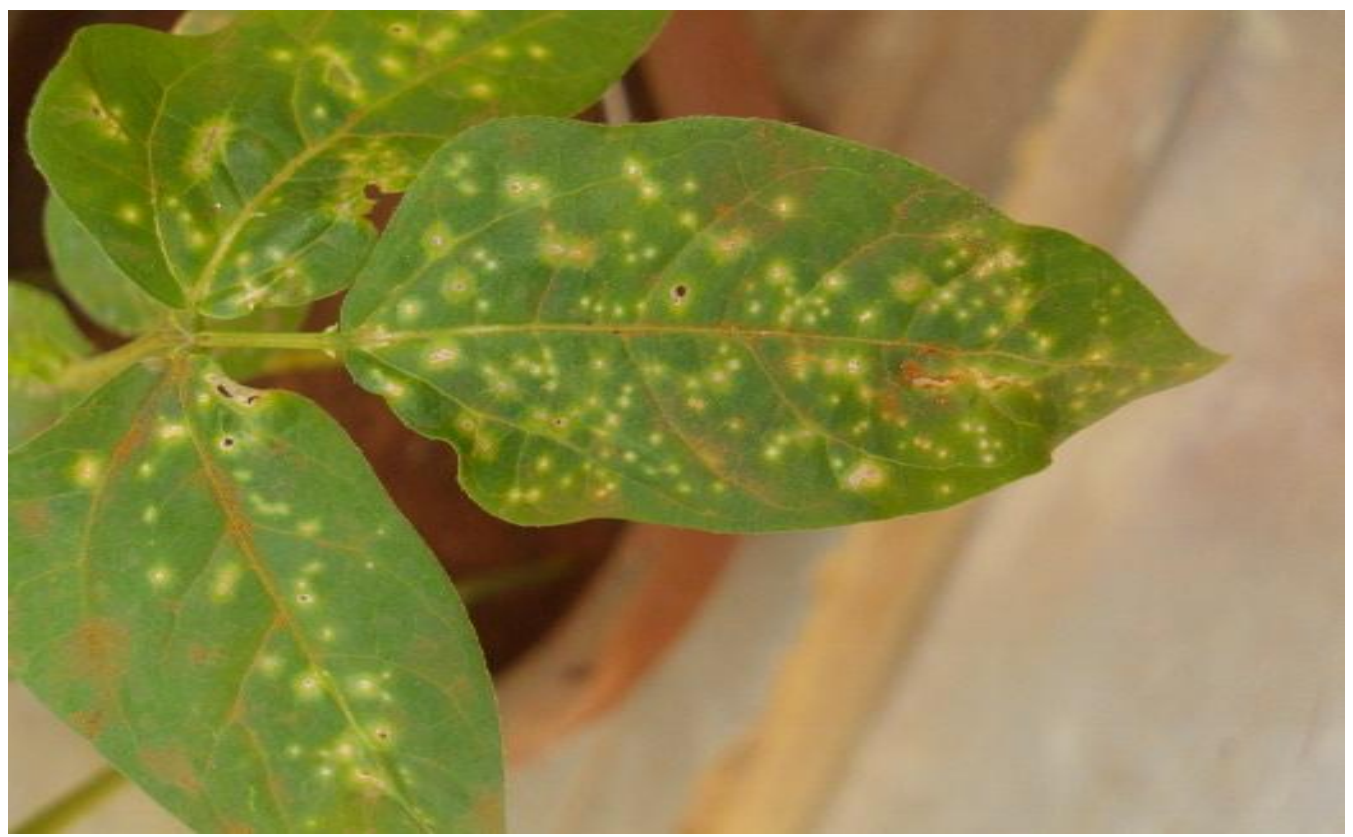

Fig.4 Veinal necrosis along with chlorosis on cowpea

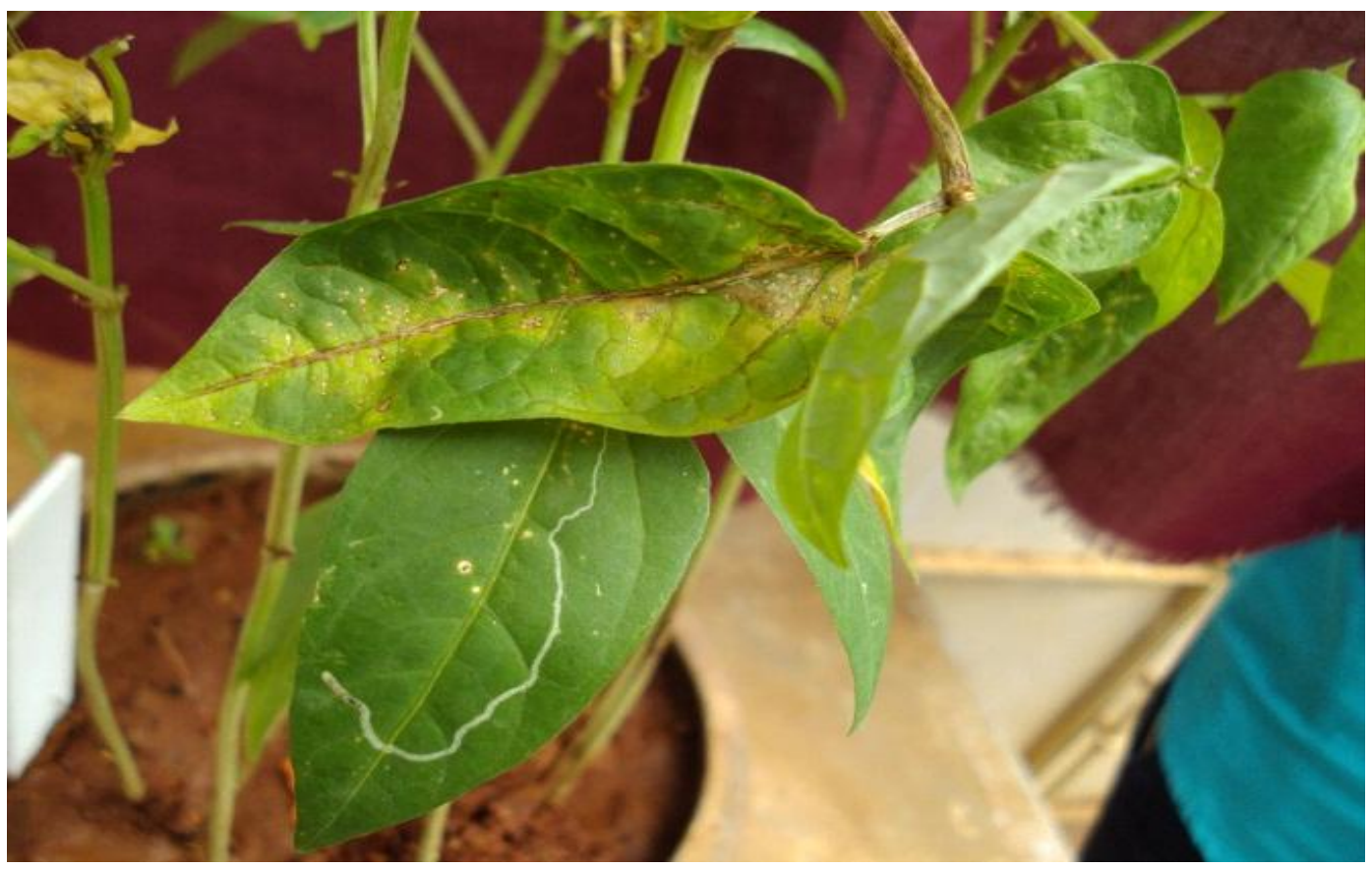

There was also brown necrotic discoloration starting from top of the plant towards the stem where it caused stem necrosis. The virus culture was maintained regularly on cowpea plants and used for further studies.

\section{Physical properties}

The maximum lesions were observed on cowpea plants inoculated with unheated sap extracted from blackgram (58 lesions) 
followed by $40^{\circ} \mathrm{C}$ (35.75 lesions). There was a progressive reduction in lesion development in response to increasing temperature. At $62^{\circ} \mathrm{C}$, sap containing TSV lost its infectivity and shows no lesions (Graph 1). The undiluted infective sap shows maximum number of lesions (54.5) followed by $10^{-1}$ dilution (29.50). Minimum number of lesions was observed at $10^{-3}$, above which there is no leisons were found to be produced. Infectivity were found to be decreased with the increase in dilution (Graph 2). Longivity test revealed that the sap immediately extracted from the Blackgram leaves were capable of producing maximum number of lesions (50) followed by 10 min storage (38.5). The infective sap remains viruliferous upto $24 \mathrm{~h}$ from the extraction after the infectivity were found lost (Graph 3).

The study of physical properties of blackgram inciting tobacco streak virus revealed that the virus infectivity was completely lost at a dilution of $10^{-5}$ and infectivity were lost in response with the increased dilution. Similar reports were given by Lavanya (2001) where sunflower necrosis virus lost its infectivity at $10^{-4}$ and $10^{-5}$.

Thermal inactivation point of TSV was found at $62^{\circ} \mathrm{C}$. This agrees with Ramaiah et al., (2001) in case of sunflower necrosis virus in which the thermal inactivation point was at the range of $50^{\circ} \mathrm{C}$ to $60^{\circ} \mathrm{C}$.After the extraction TSV remains infective upto $24 \mathrm{~h}$ but, the maximum number of lesions were observed on the sap that used immediately after the extraction which was correlated with the findings of Ladhalakshmi (2002). From the present study it is concluded that TSV causing necrosis diseases in blackgram, remains active and produces a greater number of lesions only at the temperature below $62^{\circ} \mathrm{C}$ and in addition the increase in dilution progressively reduces the symptom expression while the sap which were inoculated immediately after extraction was found to cause numerous lesions with high infectivity.

\section{References}

Bhat, A.I., Jain, R.K. and Ramiah, M. (2002a). Detection of tobacco streak virus from sunflower and other crops by reverse transcription polymerase chain reaction. Indian Phytopath, 55: 216-218.

Bhat, A.I., Jain, R.K., Chandhary, V., Krishna Reddy, M., Ramiah, M., Chattannavar, S.N. and Varma, A. (2002 b) Sequence conservation in the coat protein gene of Tobacco streak virus isolates causing necrosis in cotton, mungbean, sunflower and Sun-hemp in India. Indian $J$. Biotech., 1: 350-356.

Costa, A.S. 1945.The relationship between American tobacco streak and Brazilian "necrosebranca" or "couve". Phytopathology., 35:1029-1030.

Fulton, R.W. 1970. The role of particle heterogenecity in infection by tobacco streak virus. Virology, 41: 288.

Gracia, O. and J.M. Feldman. 1974. Tobacco streak virus in pepper. J. Phytopathology., 80: 313-323

Guo, D., Edgar Maiss and Gunter Adam. 1999. Ilarvirus isolation and RNA extraction. In: Methods in Molecular Biology, Plant Virology Protocol. Foster, G.D. and Taylor, S.C. (Eds.) Humana Press Inc., Totowa. pp. 171181.

Hull, R. (2009). Mechanical inoculation of plant viruses. Current Protocols in Microbiology, 13, 16B.6.1-16B.6.4.

Johnson, J.1936. Tobacco streak, a virus disease. Phytopathology, 26: 285-292

Kang, B.C., Yeam, I and Jahn, M.M. 2005. Genetics of plant virus resistance. Annual Review of Phytopathology. 43: 581-621. 
Ladhalakshmi, D. (2002). Purification, characterisation, Antiserum production and management methods for a necrosis virus associated with urdbean. M.Sc. (Ag.) Thesis, Tamil Nadu Agrl. Univ., Coimbatore, India

Lava Kumar, P. 2008. Emergence and Spread of Tobacco streak virus Menace in India and Control Strategies. Indian Journal of Plant Protection, 36 (1):1-8.

Lavanya, N. (2001). Establishment of a necrosis virus in sunflower and studies on induced resistance using antiviral substances and a biocontrol agent, Pseudomonas fluorescens. M.Sc. (Ag.) Thesis, Dept. of Plant Pathology. Tamil Nadu Agrl. Univ., Coimbatore, India. P. 132

Narayanasamy, P. and Jaganathan, T. 1973 Vector transmission of black gram leaf crinkle virus. Madras Agric. J. 60(7): 651-652.

Prasada Rao, R.D.V.J., Reddy, A.S., Chander Rao, S., Veraprasad, K.S., Thirumala Devi, K., Nagaraju, Muniyaapa, V. and Reddy, D.V.R. 2000. Tobacco streak ilarvirus as causal agent of sunflower necrosis disease in India. J. Oilseeds Res., 17(2): 400-401.

Ramiah, M., Bhat, A.I., Jain, Ahlawat, Y. S., Prabhakar, K. and Varma, A. 2001. Partial characterization of an isometric virus causing sunflower necrosis disease. Indian Phytopath., 54(2): 246250

Sanjay Srivastava and Alok, K. Singh. 2010. Changes in catalase activity and total protein content in urdbean [Vigna mungo (L.) Hepper] plants as a result of ULCV infection, Indian J.Sci.Res. 1(2): 67-69.

Shyam Singh and L.P. Awasthi. 2009. Plant products for the management of yellow mosaic disease of mungbean and urdbean The Journal of Plant Protection Sciences, 1(1):87-91.

Vemana, K. and Jain, R.K. 2010. New experimental hosts of Tobacco streak virus and absence of true seed transmission in leguminous hosts. Indian J. Virology, 21(2): 117.

\section{How to cite this article:}

Natarajan Subramani, R. Kannan, V. Ramamoorthy and Uma Sankareswari, R. 2018. Physical Characteristics of Black Gram Necrosis Inciting Tobacco Streak Virus on the Cowpea. Int.J.Curr.Microbiol.App.Sci. 7(09): 2407-2414. doi: https://doi.org/10.20546/ijcmas.2018.709.299 